\title{
Modern Milliyetçilik Kuramları Açısından 19. Yüzyıl Osmanlı İmparatorluğu Fikir Akımları
}

Currents of Thought in the Ottoman Empire of 19th Century in terms of Modern Nationalism Theories

\section{Yavuz Çilliler}

\section{Öz}

Bu makalede; 19. yüzyıl sonunda çökmekte olan Osmanlı İmparatorluğu’ndaki kötüye gidişi durdurmak ve etnik milliyetçiliklerin İmparatorluğu parçalamalarını engellemek adına geliştirilen fikir akımları modern milliyetçilik kuramları çerçevesinde incelenmiştir. Batıcılık dışındaki bu akımlar -Osmanlıcılık, İslamcılık ve Türkçülük-, içerik açısından günümüz milliyetçilik literatüründeki tanımlar kapsamında değerlendirilebileceğinden, teritoryal (sivil-batı tipi) ve etnik (kültürel/doğu tipi) milliyetçilik karşıtllğ̆1 üzerinden yorumlanmıştır.

İncelemenin amacı; dönemin etnik milliyetçiliklerinin insan doğasına hitap eden güçlü motiflerine karşı, rasyonel siyasal formlar vadeden teritoryal milliyetçiliklerin başarısızlıklarının açıklanmasına katkı sağlamaktır. İnceleme sonunda; teritoryal milliyetçiliklerin sivil ideallerinin etnik milliyetçilikler tarafından kullanılmasının, milliyetçilik projelerinin kitleselleşebilmelerinin -halk tarafından benimsenmelerinin-, güçlü devletlerin sömürgecilik emellerine etnik milliyetçiliklerin alet edilmelerinin ve İmparatorluğun alt kültürler açısından cazibesini yitirmesinin yanında, ayrılıkçı hareketleri durdurabilecek güce de sahip olmadığının önemi vurgulanmıştır.

Anahtar Kelimeler: Osmanlı İmparatorluğu, Fikir Akımları, Teritoryal/Etnik Milliyetçilik

Yrd. Doç. Dr., İstanbul Gelişim Üniversitesi, İktisadi İdari ve Sosyal Bilimler Fakültesi, Siyaset Bilimi ve Uluslararası İlişkiler Bölümü, ycilliler@gelisim.edu.tr

Bu makale iThenticate sistemi tarafından taranmıştır.

Makale gönderim tarihi: 09.06.2015

DOI: $10.17550 /$ aid.76834 


\begin{abstract}
In this article; currents of thought developed in order to stop going worse of the Ottoman Empire crumbling at the end of the 19th century and to prevent the fragmentation of the Empire by ethnic nationalisms have been investigated in the framework of modern nationalism theories. Because currents of ideas but Westernizaton -Ottomanism, Islamism and Turkismin term of its contents are evaluated to be in the scope of contemporary nationalism literature, these ideas has been interpreted through the dichotomy of territorial (civil/western type) and ethnic (cultural / eastern type) nationalisms.

The purpose of the review is to contribute to the explanation of the failure of territorial nationalisms promising rational political forms against powerful patterns of ethnic nationalisms that appeal to human nature. At the end of the review; the use of civil ideals of territorial nationalism by ethnic nationalisms, popularization of nationalism projects -internalization by public-, exploiting of ethnic nationalisms by strong states for the colonial aspirations, losing charm of the Empire for subcultures and besides that the lack of power to stop the separatist movement are emphasized for their importance
\end{abstract}

Keywords: Ottoman Empire, Currents of Thought, Teritorial/Ethnic Nationalism 


\section{Giriş}

19. yüzyıl sonları, Osmanlı ve Avusturya-Macaristan gibi imparatorlukların çökmekte olduğu ve ulus devlet formlarının meşru zemini erozyona uğrayan bu siyasal formları ikame ettikleri bir dönemdir. Batı'da egemenliğin kaynağı "Deo"dan "populo”ya (ilahi olandan dünyevi olana) aktarılınca, egemenliğin meşru etki alanının -ulusal sınırların- tanımlanması sorunu ortaya çıkmıştır. Bir kısım ülkelerde bu sorun kültürel sınırlar, bazılarında ise teritoryal sınırlar üzerinden tanımlanarak aşılmaya çalışılmış, milliyetçilikler daha rasyonel bir meşruiyet vaadi ile ulusları tarihin öznesi haline getirmişlerdir.

Osmanlı İmparatorluğu'nun da, Weberyan anlamda patrimonyal bir sistem olarak gelişmelerden etkilenmesi kaçınılmaz hale gelmiştir. İmparatorluk sınırları içerisinde güçlenen ayrılıkçı etnik milliyetçilik hareketlerine karşı, yöneticiler tarafindan alternatif milliyetçi projeler -Osmanlıcılık, İslamcılık ve Türkçülük- devreye sokulmuş, ancak önerilen siyasal birlik formları çeşitli nedenler ile gerçekleştirilememiştir.

Öngörülen başarıyı elde edemeyen son dönem Osmanlı fikir akımlarının günümüz milliyetçilik perspektifi ile değerlendirilmesinin, şimdiye kadar yoğun olarak çalışılmış bu alana katkı sağlayacağ düşünüldüğünden ilk bölüm milliyetçilik teorisine ayrılmıştır. Öncelikle üzerinde henüz akademik görüş birliği sağlanamamış olan "milliyetçilik" kavramı konusunda bir tanıma ulaşmaya çalışılmıştır. Her ne kadar milliyetçilik; ideolojiden projeye, söylemden inşaya kadar farklı kapsamlarda yorumlanmış olsa da mevcut milliyetçilik tipolojilerini açıklayabilecek kabul edilebilir bir tanımın elde edilmesi hedeflenmiştir. İkinci bölümde ise dönemin fikir akımları incelenmiş ve doğu-batı tipi milliyetçilik tipolojisi içerisinde konumlandırılmışlardır. Özellikleri ve iktidar projesi olmaları dikkate alındığında, gerçekte birbirlerinden pek de farklarının olmadığına, devletin bu fikir akımlarını siyasi bir aygıt olarak kullandığına değinilmiştir. Çalışmanın son bölümünde, "kurtuluş projesi” niteliğindeki bu fikir akımlarının Osmanlı İmparatorluğu'nun dağılmasını engellemek konusundaki yetersizlikleri açıklanmaya çalışılmıştır. Sivil idealler ile etnik milliyetçiliklerin kaynaştırılma gayretlerinin, uluslararası yapının, merkezi devletin alt kültürler açısından cazibesinin, devletin gücünün ve halk desteğinin önemi vurgulanmıştır. 
Günümüzde etnik milliyetçilikler, eğer asimilasyon uygulamaları, sistematik insan hakları ihlalleri ve etnisitelerin temsili sorunları yok ise uluslararası yapı tarafindan en azından normatif düzeyde desteklenmemektedirler. Ancak bu paradigma İkinci Dünya Savaşı sonrası Alman milliyetçiliğine tepki olarak gelişmiştir. Vesayet, sömürge ve işgal altındaki ülkelerin bağımsızlıklarını kazanmaları ve SSCB ile Yugoslavya'nın fiilen çöküşü hariç tutulduğunda -ki bu yeni devletlerin kuruluşu etnik milliyetçilikler ile açıklanmamaktadır-, 20. yüzyılın ikinci yarısında ulus devlet oluşumu ile sonuçlanan etnik milliyetçiliklere nadiren rastlanır. İkinci Dünya Savaşı öncesi dönem ise tam tersi bir paradigmanın etkisi altındadır. Yükselen ırk ve soy birliği değerleri, Lenin ve Wilson'da ifadesini bulan "halkların kendi kaderini tayin" ilkesi, dönemin etnik milliyetçiliklerine teritoryal milliyetçilikler karşısında daha itibarlı bir konum sağlamıştır. Evrensel değerlerdeki bu değişim çalışma kapsamına dâhil edilmemekle birlikte, ifade edilmemesinin eksiklik olacağı düşünülmüştür.

\section{Milliyetçilik ve Milliyetçilik Türleri}

İngilizcede "nation-national-nationalism" şeklinde türetilen kelime, Türkçeye "millet-milli-millicilik" veya "ulus-ulusal-ulusalcılık" yerine milliyetçilik (nationalitism) ve ulusçuluk (nationism) olarak çevrilmiştir. Çevirideki farklılık ile akademik tanım konusundaki fikir ayrılıkları, milliyetçilikten ne anlaşıldığı ile asıl içeriği arasındaki farklılığı artırdığından, kavramı tarif ederek tanımaya başlamak faydalı olabilir. Öncelikle milliyetçilik vatanseverlik (patrie-patriotism) değildir. Milliyetçilik bir ırkın, halkın veya topluluğun üstünlüğüne duyulan inanç (racism, chauvinism) da değildir. Bu tür duygulanımlar antik çağdan itibaren gözlenebilir olgulardır. Milliyetçilik modern çağa aittir ve ulus, devlet ve ulus devletlerin kuruluşu ile ilgili bir fenomendir. Ernest Gellner'e göre milliyetçilik, "siyasal birim ile ulusal (kültürel) birimin çakışmalarını öngören siyasal bir ilkedir", Anthony D. Smith'e göre ise, "bir halk adına özerklik, birlik ve kimlik edinmek ve bunu sürdürmek için oluşturulan ideolojik bir harekettir"2. İlk tanı-

1 Ernest Gellner, Uluslar ve Ulusçuluk, çeviren: Büşra Ersanlı, Günay Göksu Özdoğan, 2.bask1, İstanbul, Hil Yayın, 2008, s.71.

2 Anthony D. Smith, Ethno-Symbolism and Nationalism: A Cultural Approach, New York, Routledge, 2009, s.61. 
ma göre ya her etnisitenin kendi devleti olacak (etnik milliyetçilik), ya da her devlet tebaasının türdeşliği ölçüsünde meşru sayılacaktır ki bu ilke de devletlerin türdeş topluluklar ideali beslemelerine neden olacaktır (resmi milliyetçilik-homojenleştirme) ${ }^{3}$. Bu tanımda meşruiyet, iktidarın yönetilenler ile aynı etnisiteden olmasına bağlıdır. Smith'in tanımında ise milliyetçilik, öncelikle milli birliği sağlayan bir ideoloji olmakla birlikte, millet için bir kimlik temin aracıdır ve milletin bu kimlik ile tarif edilebileceğini ima eder. Bu tanıma konu olan millet; dil, din, kültür, ırk gibi nesnellikler ile bir öze indirgenmeye çalışılabileceği (etnik milliyetçilik) gibi, siyasi birlik formu (teritoryal/sivil milliyetçilik) olarak da kabul edilebilir. Özerklik, ise milletin meşru iktidarının diğer milletlerden bağımsızlığına ve ülke toprakları ve toplum üzerindeki egemenliğine vurgu yapar. $\mathrm{O}$ halde sadece her iki tanım birlikte kullanıldığında, çalışmamıza konu olacak etnik, teritoryal ve resmi milliyetçilik tipolojileri açıklanabilir. Dolayısıyla, Gellner'in tanımını Smith'in tanımı ile genişletirsek, "siyasal birim ile kültürel veya teritoryal birimin çakışmasını öngören ve çakışma alanında siyasal birimin egemenliğini meşru sayan ilke" şeklinde bir milliyetçilik tanımına ulaşabiliriz ${ }^{4}$.

Muhtelif milliyetçilik tipoloji çalışmalarından ${ }^{5}$, hiçbiri tüketici olmamakla birlikte en fazla kabul göreni, Hans Kohn'un Batı-Doğu tipi milliyetçilik ayrımıdır ${ }^{6}$. Örneğin Fransız milliyetçiliği; belirli s1nırlar içerisinde yaşayan bir topluluğu millet olarak tanımladığı ve

3 Merkezi devletin; egemenlik sınırları içerisindeki tüm etnisitelerin aslında tek bir kültürün parçası oldukları iddiası ile kültürel (dil, din, gelenek, görenek...) alanda homojen bir toplum yaratma çabası olarak tanımlanan bir milliyetçilik türüdür. Massimo d'Azeglio'nun "L'Italia è fatta. Restano da fare gli italiani, -İtalya'yı kurduk, sıra İtalyanları yaratmakta-" ifadesi ile anılır.

4 Modern milliyetçilik teorisyenleri tarafından milliyetçilik genel olarak; fenomenin birbirinden farklı yönleri öne çıkarılarak, ya ulus ve/veya devlet inşası kapsamında geleneklerin icat edilmesi ve banal sembollerin kullanılmasını içeren bir proje, ya kitleleri mobilize edebilen bir ideoloji ya da bilincimizi şekillendirerek dünyayı anlamlandırmamızı sağlayan bir söylem olarak tanımlanmıştır. Yavuz Çilliler, Etnik Sorunlar, Demokratikleşme ve Bask Milliyetçiliği, Ankara, Alter Yayıncılık, 2014, s.30-33.

5 Muhtelif tipoloji çalışmaları için bakınız Umut Özkırımlı, Milliyetçilik Kuramları: Eleştirel Bir Bakış, 3.Baskı, Ankara, Doğu Batı Yayınları, 2009, s.60,61.

6 Hans Kohn, "Western and Eastern Nationalisms", Nationalism, John Hutchinson, Anthony D.Smith (eds.), New York, Oxford University Press, 1994, s.162-165. 
milletin siyasal bir birlik formu olduğu, millete katılımın veya ondan ayrılmanın kişinin veya alt grupların iradesine bırakıldığı için sivil/ teritoryal/batı tipi bir milliyetçiliktir. Dolayısıyla iktidar meşruiyetini Fransız Devriminin özünde olan milli iradenin tecessümünden alır, siyasal topluluk istediği müddetçe iktidar meşrudur. Alman milliyetçiliği ise öze dayalı bir millet tanımından yola çıktığı için etnik/doğu tipi bir milliyetçiliktir. Aydınlanmanın akılcılığının aksine birey ve duyguyu vurgulayan Alman Romantizmi Alman milletini “dil” nesnel özü ile tanımlamıştır. Millete aidiyet seçime bağlı değildir, zorunludur, çünkü millet doğal bir topluluktur ve doğum ile birlikte milletin üyesi olunur. İktidar, o topluluğun içinden çıktığ 1 ve topluluğun bir parçası olduğu için meşrudur.

Greenfeld, Almanya'da ulus düşüncesinin 18. yüzy1l boyunca bilindiğini ve neredeyse sıradanlaştığını, 1806 yılında Prusya'nın Fransızlar karşısında uğradığı yenilginin Alman milliyetçiliğini dünyaya taşıdığını belirtmektedir? ${ }^{7}$. Dolayısıyla yaklaşık birbiri ile aynı dönemlerde ve etkileşim içinde gelişen doğu ve batı tipi milliyetçilik türlerinden doğu tipi (etnik) milliyetçilikte meşruiyet kendiliğinden kazanılırken, teritoryal milliyetçilikte siyasi form topluluğun üyeleri tarafından arzu ediliyor olmalıdır. Bunun için de mevcut formun alt kültürler için rasyonel bir cazibeye dayanması -Quebec ve K. İrlanda referandum sonuçlarının gösterdiği gibi- gerekir. Rasyonel çıkar ortadan kalktığında ve etnik milliyetçilikler filizlendiğinde tek millet olarak varlığını sürdürmek için devletler -Ortadoğu'daki farklı alt kültürlere sahip otoriter rejimler gibi- güce gereksinim duyarlar.

Kısaca; her ne kadar milliyetçilik anlatılarında geçmişe dair altın çağlar, mitler ve semboller ile keşfedilmiş gelenekler önemli yer tutsa da, milliyetçilik öncelikle milleti tanımlar, bu tanım iktidarın meşruiyetine temel sağlamalıdır. Kültürel ve siyasi alan çakıştığı için kendiliğinden meşru etnik milliyetçilik, meşruiyeti iradi olan teritoryal milliyetçilikten tam da bu nedenle -doğal olduğu iddiası ile- daha güçlü motifler taşır. Teritoryal milliyetçiliklerin, alt etnik milliyetçilikler ile karşı karşıya kaldıklarında, alt kültürler için rasyonel çıkar sağlamıyorlar ise, varlıklarını sürdürmeleri güç ile mümkündür.

7 Liah Greenfeld, “Alman Milliyetçiliğinin Doğuşu”, Doğu Batı, çeviren: Yasemin Şahin, cilt 10, s.39, Kasım-Ocak 2006-2007, s.32. 


\section{Osmanlı İmparatorluğu'nda Fikir Akımları}

"Din" gibi geleneksel meşruiyet formlarının çökmesi ile birlikte Batı devletlerindeki iktidarlar meşruiyetlerine temel kazandırmak için ulus devlet tasavvurlarının kaynağı olan milliyetçilik ideolojisine başvurmuşlardır. Günümüz Türkiye'sinin de siyasi kompozisyonunun bir parçasını oluşturan milliyetçilik ve milli kimlik ile ilgili görüşler, genellikle kökenleri Osmanlı İmparatorluğu'na uzanan sürekliliklerdir. Osmanlıcılık, İslamcılık, Türkçülük ve Batıcılık olarak adlandırılan ${ }^{8}$ ve Osmanlı İmparatorluğu'nun son döneminde siyasi hayata yön veren bu akımlar, bugün de değişen oranlarda milliyetçi görüşlere kaynaklık etmektedir.

$\mathrm{Bu}$ yaklaşımlar, çökmekte olan bir imparatorluğu kurtarma girişimleri olarak ifade edilebileceği gibi, günümüzdeki anlamıyla milliyetçilik kapsamında da değerlendirilebilir. Osmanlıcılık, İslamcılık ve Türkçülük akımlarının her birinin içeriğinde bir "millet" tanımı ve kabulü vardır, her biri tanımladığı millete uygun egemen siyasal formu (devleti) oluşturmayı veya var olanı korumayı hedeflemekte, ayrıca dönemin iktidarları anılan milli kimlik üzerinden meşruiyet talep etmektedirler. Bu düşünce ile Osmanlı Mebusan Meclisleri'nde tüm dini toplulukların -alt kimliklerin- temsiline de imkân tanınmıştır. Diğer bir ifade ile bu fikir akımları; siyasi iktidar (siyasal birim) ile tanımladıkları milletin (kültürel ve teritoryal birimin) uyuştuğu, dolayısıyla iktidarın egemenliğinin meşru olduğu iddiasındadırlar. Bu unsurları içinde barındıran Osmanlı fikir akımlarının birer milliyetçilik projesi olduklarını söylemek mümkündür. Sadece dönemin "İçtihad" isimli dergisinde uzun süre tartışılan "Batıcılık" yaklaşımı -Abdullah Cevdet'in, Celal Nuri'nin veya diğerlerinin savunduğu- ${ }^{9}$ bir milliyetçilik projesi için yeterli unsurlardan mahrumdur. Batıcılık aslında diğer akımlar içerisinde farklı mahiyetlerde mevcut olan ${ }^{10}$ bir kalkınma-kur-

8 İlber Ortaylı, Taha Akyol, Osmanlı Mirası, 1. Baskı, İstanbul, Timaş Yayınları, 2010, s. $140-144$.

9 Abdullah Cevdet batının sahip olduğu her şeyin, Celal Nuri ise batının sadece tekniğinin -Japonya gibi- alınmasını savunmuşlardır. Suna Başak, Kültür Olgusu Analizleri ve Üç Tarz-ı Siyaset, Ankara, Odak Yayınevi, 2004, s.58.

10 Emre Kongar Batıcılığı, Türklerin batıya göçü ve Malazgirt Savaşı ile, Halil İnalcık ise Osmanlı Devletinin doğuşu ile başlatır. Emre Kongar, Tarihimizle Yüzleşmek, İs- 
tuluş yöntemidir. Çünkü bir millet tasavvuru, altın çağ miti veya nesnel özü yoktur, sadece bir ilerleme projesi ve kurtuluş çaresidir.

Osmanlı İmparatorluğu son dönemi milliyetçiliklerinin tamamı -Osmanlıcılık, İslamcılık ve Türkçülük- zaman zaman aynı taşıyıcı entelijensiyayı kullanmışlar ${ }^{11}$ ve Batı siyaset felsefesi ile etkileşim içinde gelişmişlerdir. Çökmekte olan bir İmparatorluğu ayakta tutmak, eski gücüne kavuşturmak ve Aydınlanma sayesinde Batı'nın sahip olduğu üstünlüğü tekrar elde etmek ortak amaçlarıdır ve vatansever bir içeriğe sahiptirler. Halk tabanından gelen talepler doğrultusunda olmayıp, elitist ve yukarıdan aşağıya endoktriner bir yol izleyerek gerekli halk tabanını yakalamaya çalışmışlardır. Ayrıca, filizlendikleri dönemin hâkim siyasetinin başarısız olduğu düşüncesiyle, öncel siyasete tepki olarak gelişmişlerdir.

İlk kez net bir ayrım ile Yusuf Akçura'nın "Üç Tarz-1 Siyaset” adlı makalesinde ifade edilen ve Osmanlı İmparatorluğu'nun son döneminde siyasete yön veren Osmanlıcılık, İslamcılık ve Türkçülük olarak adlandırılan milliyetçilik projeleri; günümüzde de milli görüş, muhafazakâr demokrat, liberal görüş, sosyal demokrat, ülkücü hareket, ulusalcılık gibi siyasi yaklaşımlara, kendilerine özgün milliyetçilik sentezlerini oluşturmaları konusunda gerekli birikimi sağlamaktadırlar.

\section{Osmanlıcılık}

Akçura tarafından Osmanlıcılık; "Müslim ve gayri-Müslim ahaliye

tanbul, Remzi Kitabevi, 2006, s.45., Halil İnalcık, Osmanlılar: Fütühat, Imparatorluk, Avrupa ile İlişkiler, İstanbul, Timaş Yayınları,2010, s.244. Ülken'e göre ise; Batıcılık hareketi, III. Ahmet ile başlamış ve III. Selim ile ilk başarısını kazanmıştır. Tanzimatçılar içerisinde "medeniyetçilik" adıyla ifadesini bulan Batı değerleri, Osmanlıcılığın önemli bir yanını oluşturmuştur. Onlar daha çok "Osmanlı birliğini” korumak kaydıyla batılılaşma taraftarı olmuşlardır. Hatta Batıcılık, İslamcılık akımı içerisindeki "modernist” grup içerisinde dahi taraftar bulmayı başarabilmiştir. Aynı zamanda Jön Türkler arasında gelişen "Batıcılık" ise daha radikal değişim taleplerine kaynaklık etmiştir. Hilmi Ziya Ülken, Türkiye'de Çağdaş Düşünce Tarihi, 2.Baskı, İstanbul, Ülken Yayınları, 1979, s.202.

11 "İttihatçılar arasında, İslamcılar ile birlikte Avrupacılar ve Türkçüler de vardı. Nitekim Hürriyet ve İtilaf Partisi içinde de İslamcılar ve Avrupacılar buluşmuşlardı. Fakat siyasi gerginlik arttıkça İslamcıların modernist diye tanınan kısmı İttihatçılarla birleştiği halde, kaidelere ve geleneğe bağlı kalan İslamcılar Hürriyet ve İtilaf Partisinde çoğaldılar... “ Ülken, Türkiye’de Çağdaş Düşünce Tarihi, s.196. 
aynı siyasi hakları tanımak ve vazifeleri yüklemek, böylece aralarında tam müsavat husule getirmek, fikir ve din açısından tam serbesti vermek, bu müsavat ve serbestiden faydalanarak, söz konusu ahaliyi aralarındaki din ve soy ihtilafına rağmen yekdiğerine karıştırarak ve temsil ederek, Amerikan milleti gibi müşterek vatanla birleşmiş yeni bir milliyet meydana çıkarmak" olarak tanımlanmıştır ${ }^{12}$. Amerika ile yapılan bu özdeşleştirme, değişik kültürlerin bir arada teritoryal bir millet oluşturması düşünüldügünnde yerindedir, ancak savaşarak İngiltere'den bağımsızlıklarını kazanmaları dikkate alındığında ise sorunludur.

Bu yönelişin bir zorunluluk olduğu fikri neredeyse bütün Tanzimatçıların ortak görüşüdür. Onlara göre; devletin bekası için eski sistemin değiştirilmesi ve yenilenmesini sağlayacak bir toplum modeli projesi uygulamaya konulmalıdır. İkinci Mahmud'un 1826'da ifade ettiği, “Ben tebaamın Müslüman'ını camide, Hristiyan'ını kilisede, Musevi'sini havrada fark ederim, aralarında başka bir fark yoktur" şeklindeki sözleri Osmanlıcılık kavramının ana ilkesini teşkil eder ${ }^{13}$. Bu dönemin âdem-i merkezi yönetim tarzına tepki duyan Tanzimatçılar da (Reşid Paşa, Ali ve Fuad Paşalar) bireysel bağlardan müteşekkil millet yaratmak amacıyla Osmanlıcılığı savunmuşlardır. Bu görüş taraftarlarına göre; ülkenin sahibi vatandaşlardır, "Osmanlı" olarak vatandaşlık statüsü ise dini kimliklere bakılmaksızın devlete sahip çıkılmasını gerektirmektedir. 1839 Tanzimat Fermanı ve 1856 Islahat Fermanı'nın kanun önünde eşit Osmanlı vatandaşlığı ise 1864 Tabi'yet-i Osmaniyye Kanunu ile yasal niteliğe kavuşmuştur ${ }^{14}$. Bu tanım, her ne kadar imparatorluk sınırları içerisindeki her bireyi vatandaşlık temelinde eşit bireyler yapmayı vadetse de, vatandaş hala tebaa idi ve milli iradenin temsili sorunu görmezden gelinmekteydi. Oysaki egemenliğin meşru kaynağı Fransız İhtilali ile halk olmuştu.

Ali ve Fuat Paşaların kameralist-aydın despotik yönetim tarzlarına reaksiyon olarak gelişen, Namık Kemal'in "hürriyet ve vatan"

12 Yusuf Akçura, "Üç Tarz-1 Siyaset”, Üç Tarz-1 Siyaset: Yusuf Akçura, Mehmet Ali Erdem (Editör), 2.Bask1, Ankara, Lotus Yayınevi, 2005, s.35-36.

13 Azmi Özcan, “Osmanlıcılık”, Diyanet İslam Ansiklopedisi, cilt 33, Türkiye Diyanet Vakfi Yayınları, 2007, s.485.

14 Kemal Karpat, İslam'ın Siyasallaşması, 4.Baskı, İstanbul, İstanbul Bilgi Üniversitesi Yayınları, 2010, s.583. 
vurgusuyla ideolojik temelini hazırladığı ve Mithad Paşa'nın yönettiği Genç Osmanlı Hareketi de Osmanlıcılık yaklaşımını savunmuştur ${ }^{15}$. Ancak bu kez halkın temsilinin önemi kavranmış ve meşruti bir yönetim talep edilmiştir. İttihad-1 Osmani'nin gayr-i müslimleri de kapsadığı söylemi kitleselleştirilerek, 1876 Anayasa'sı ile meşruti monarşi kurulmuş, yapılan seçimlerde 240 kişilik Osmanlı meclisi, 180 müslim 60 gayrimüslim temsilciden oluşturulmuştur ${ }^{16}$. Osmanlıcılığın cisimleştiği bu siyasal yapı ise 1877-78 Rus harbinin başlaması gerekçe gösterilerek II. Abdülhamid'in meclisi fesih etmesiyle sona ermiştir.

Osmanlıcılığın bir iktidar projesi olarak 19. yüzyılda uygulanmaya başlanması rastlantı değildir. Osmanlı İmparatorluğu, Avusturya ve Rusya ile girdiği savaşlarda yenilmesinden dolayı 1699, 1718 ve 1774 tarihlerinde toprak kaybetmiştir. Ancak 1804 Sırp isyanı ve 1821 Yunan isyanı Osmanlı tebaasından bir unsurun merkezi devlete kar\$̧1 mücadelesi olması nedeniyle öncekilerden farklıdır. Bu toprakların kaybedilmesinde güçlü devletlerin emperyalist politikalarına milliyetçilik duygularını alet etmelerinin katkısı büyüktür ${ }^{17}$. Bu tür ayrılıkları engellemek için geliştirilen Osmanlıcılık teritoryal bir milliyetçilik ideolojisidir. İmparatorluğun mevcut sınırlarının muhafaza edilebilmesine imkân tanımak için muhtelif dini toplulukları Osmanlı kimliği ile birleştirmek istemiş ve iktidarın egemenliğini meşrulaştırmak için 1876'dan itibaren tüm kültürlerin temsilini mümkün kılmış bir siyasal birlik projesidir.

Sırp ve Yunan ayrılıkçı hareketlerini ise her etnisitenin kendi devletini kurmasına yönelik bir etnik milliyetçilik -doğu tipi milliyetçilik- daha iyi açıklamaktadır. Karpat, Balkan Hristiyanları arasındaki milliyetçi hareketlerin; bölgede vergiler dışında sömürge pazarı olmayan Osmanlı İmparatorluğu'nun “sömürgeci” yönetiminden bir kurtuluş hareketi olmadığını, çöken geleneksel düzenin sonuçlarına

15 Şerif Mardin, “19. Yüzyılda Düşünce Akımları ve Osmanlı Devleti”, Şerif Mardin: Türk Modernleşmesi, Mümtazer Türköne, Tuncay Önder (Editörler), İstanbul, İletişim Yayınları, s.86, 87.

16 Veli Yılmaz, Siyasi Tarih, İstanbul, Harp Akademileri Basımevi, 1998, s.115.

17 Alan Palmer, Verfall und Untergang des Osmanischen Reiches, çeviren: Maria Rosken, Ilse Strasmann, München, Wilhelm Heyne Verlag, 1992, s.127; Y1lmaz, Siyasi Tarih, s.166, 182 
karşı başlayan protesto hareketlerinin sonradan milliyetçi hareketlere evirildiğini ifade etmiştir ${ }^{18}$. Aslantaş'a göre Sırp isyanları; Osmanlı İmparatorluğu'nun Balkanlar'da 19. Yüzyıl arifesinde yaşadığı sosyal, ekonomik ve idari sorunların bir sonucu olarak ortaya çıkmış, 1807 yılından itibaren isyan istikamet değiştirmiş, Avrupa devletleri arasındaki ilişkilere dayalı bir isyana evirilmiş, milliyetçilik duygularının ön plana çıkması ise Alman Romantik hareketinin etkileri neticesinde yüzyıl ortalarında gerçekleşmiştir ${ }^{19}$. 1877-78 Rus Savaşı ile Osman11 İmparatorluğu Avrupa Hristiyan topraklardaki hâkimiyetini büyük oranda yitirmiş, böylece Osmanlıcılık yaklaşımının başarısı sorgulanmaya başlamış ve Balkan Savaşları ile fikir hayatından tamamen silinmiştir.

Akçura, Osmanlıcılığın başarısızlığına da değindiği makalesinde, bu projenin gayri Müslimler kadar, Türkler ve diğer Müslüman tebaa tarafindan da benimsenemediğine dikkat çeker ${ }^{20}$. İttihad-i Osmani alt kültürlerin tamamı için rasyonel cazibeden yoksundur. Gayri Müslimler daha refah ve güçlü olan Batı'nın parçası olmaya talip iken, Müslümanlar da millet-i hâkime rolünü eşit vatandaşlık ile değişmek niyetinde değillerdir. Diğer bir önemli etken de, Avrupa sömürgecilik arayışı ile Osmanlı İmparatorluğu'nun alt etno-milliyetçilikler ile parçalanması arasındaki yakın korelasyondur. Tunaya, çeşitli etnik unsurların Osmanlı İmparatorluğu'ndan ayrılma savaşına girişmeleriyle beraber, on yedinci yüzyılın başından itibaren, "Devletler" ya da "Düvel-i Muazzama"nın (zamanın süper devletlerinin) bu ayrılıkları kışkırtıcı ve sağlayıcı bir güç olarak ortaya çıktıklarını ifade etmektedir. Birleşik bir cephe halinde Batılı devletler (İngiltere, Fransa, Almanya, Avusturya-Macaristan, Çarlık Rusya) Osmanlı ülkesinden kopma sürecini düzenlemişler, İmparatorluğun hâkimiyetini yapısal bir değişikliğe uğratmışlardır²1.

18 Karpat, İslam'ın Siyasallaşması, s.592.

19 Selim Aslantaş, “Sırp İsyanları (1804-1815): Milli Bağımsızlık Hareketi mi, Burjuva Devrimi mi, Köylü Ayaklanması mı?”, Doğu Batı, s.39, Ocak 2006-7, s.83-96.

20 Yusuf Akçura, "Üç Tarz-1 Siyaset”, s.49, 50.

21 Tarık Zafer Tunaya, Türkiye'de Siyasal Gelişmeler (1876-1938), Mütareke, Cumhuriyet ve Atatürk, 3. Bask1, İstanbul, İstanbul Bilgi Üniversitesi Yayınları, 2009, s.169. 


\section{Íslamcılık}

İslamiyet, Osmanlı İmparatorluğu'nun kuruluşundan itibaren değişen oranlarda sosyal ve ekonomik hayata etki ederek siyasi bir güce sahip olmuştur. Siyasal İslam'ın iktidar elinde siyasi bir ideolojiye, milliyetçiliğe dönüşmesi ise gayri-Müslim tebaanın büyük kısmının 1877-78 Rus Savaşı sonrasında Osmanlı yönetiminden bağımsızlıklarını kazanmaları ile gerçekleşmiştir. İslamcılık, eşit vatandaşlık tesis etme çabalar1 nedeniyle Tanzimat döneminden itibaren ihmal edilen kavm-i necip Araplar ile siyasi birliğin devam ettirilmesine yönelik bir proje olarak uygulanmaya başlanmıştır.

İslamcılık en çok; Müslümanların Batılı sömürgecilerden kurtulması gerektiğini ifade eden Cemaleddin Afgani ile anılan bir fikir akımıdır. Ona göre tüm İslam âlemi Halife'nin liderliğinde birleşmelidir. Abdülhamid'in İslamcılığı da İslam unsurlarını -evvela Osmanlı ülkelerindekileri, sonra bütün küre-i arzdakileri- soy farkına bakmaksızın dindeki ortaklıktan istifade ile tamamen birleştirmek lüzumun$\mathrm{dan}^{22}$ hareket etmiştir. İslamcılık hareketi aslında bir ahlak hareketi olarak başlamış olmasına rağmen, sonradan "İttihad-1 İslam" fikrini savunmaya kadar evirilmiştir. Ancak, İslam âleminin büyük bir kısmının İngiliz, Fransız, Hollanda ve hatta Portekiz tarafından kolonileştirildiği, dolayısıyla hürriyetleri olmayan kavimlerin birleştirilmesinin hayalden ibaret olduğu gözden kaçırılmıştır ${ }^{23}$.

Başlangıçta "Basiret Gazetesi" sayesinde taban bulan İslamc1lık, II. Abdülhamid tarafından uygulamaya konmuştur. Ahmet Cevdet Paşa, Gazi Ahmet Muhtar Paşa gibi simalar İslamcılık taraftarları olarak Padişah çevresinde konumlanmışlardır. Mehmet Akif ise başyazar-

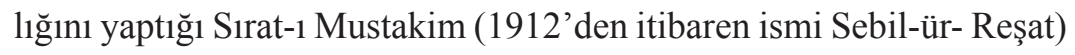
dergisi ile bu akımı benimseyen halk tabanını genişletmeye çalışmıştır. Şeyhülislam Musa Kazım, Şemsettin Günaltay ve Sait Halim Paşa da İslamcılığın savunucusu olmuşlardır.

"İslamcılık" ismi dikkate alındığında, milleti nesnel bir öze indirgediği ve bu nedenle bu akımın doğu tipi bir etnik milliyetçilik olduğu düşünülebilir. Ancak II. Abdülhamid, Balkan devletlerinin ba-

22 Yusuf Akçura, "Üç Tarz-1 Siyaset”, s.39.

23 Ülken, Türkiye’de Çăgdaş Düşünce Tarihi, s.199. 
ğımsızlığının arkasından Arapların da ayrılacaklarına ve bunun Anadolu'daki Ermeniler, Rumlar ve Kürtler için de model teşkil edebileceğine inanmıştır. Bu nedenle en azından kalan mevcut toprakların korunması için sınırlar içerisinde kalan tebaanın tanımlanması gerekmekte ve tebaa içerisindeki farklı dini ve kültürel topluluklar ortak bir kimlik ile birleştirilmelidir. Her ne kadar Ortodoks tebaa açısından "İslam" harcı resmi milliyetçilik uygulaması olarak kabul edilebilirse de, nüfusun çok daha büyük bölümünün -Türkmen, Arap ve Kürtlerin- Müslüman olduğu düşünüldügünde, İslamcılığın ortak bir kimlik niteliğine daha çok haiz olduğu söylenebilir. Bu birleştirici siyasi niteliği açısından bakıldığında İslamcılık daha çok teritoryal/sivil bir milliyetçilik anlayışıdır. Araplar ile siyasi bir birlik hedeflenmiş, mevcut İslam birliğini kavmiyet -milliyet- esasına göre parçalamak suç sayılmıştır. İktidarın meşruiyetini temellendirmek için gerekli temsil müessesesinin aktif hale gelmesi ise 1908 yılında mümkün olacaktır.

Birliğin tesisi için II. Abdülhamid, Arapların çıkarlarına hitap eden bir siyaset takip etmiş, Arap ileri gelenlerine merkezi yönetim içerisinde önemli görevler vermiş, ordudaki Arap subay oranı yüzde 10'a kadar yükseltilmiştir ${ }^{24}$. Bu sayede Arapların merkezi iktidara sadakatlerini devam ettirecekleri düşünülmüştür. Arap entelijensiyası ise bir süre Osmanlı merkezi bürokrasisi içinde yer almayı ve kültürel farklılıklarını sürdürebilmeyi yeterli bulmuşlardır ${ }^{25}$. Ancak zamanla Arap tebaa içerisindeki farklılık bilinci; İngiltere-Fransa'nın politikalarından ve Balkanlar'daki milliyetçi hareketlerden etkilenerek siyasallaşmaya başlamış, Birinci Dünya Savaşı yıllarında bağımsızlık talep eden bir Arap milliyetçiliğine bürünmüştür ${ }^{26}$. Osmanlıcılık gibi İslamcılık da Batılı emperyalist politikalar tarafından desteklenen etnik milliyetçilik karşısında birleştirici niteliğini koruyamamıştır.

24 Karpat, İslam'ın Siyasallaşması, s.593.

25 Avrupa devletlerinin Arap milliyetçiliğini uyandırma çabaları Napolyon’un Mısır seferine kadar geri götürülebilir. Napolyon komutanlarına verdiği emirlerde "Halk1 kazanmak için elinizden geleni yapınız. Eğer halkın bağımsızlığa eğilimi varsa, bu duyguyu körükleyiniz" şeklinde ifadeler kullanmış ve gelişen Yunan milliyetçiliğinin, din taassubundan daha kuvvetli etkiler yarattığına dikkat çekmiştir. Fahir H. Armaoğlu, Siyasi Tarih 1789-1960, Ankara, Sevinç Matbaa, 1964, s.96 .

26 Recep Boztemur, "Irak Milliyetçiliği: Toplumsal Bütünleşmede Ordunun Rolü ve Devletin Meşruluk Temelleri”, Doğu Batı, s.39, Ocak 2006-7, s.62; Faruk Bozgöz, “Arap Milliyetçiliği”, Doğu Batı, s.39, Ocak 2006-7, s.105. 


\section{Türkçülük}

"Dil” gibi Türklük ile ilgili kimlik öğelerinin daha erken dönemlerde oluşmasına rağmen, Türkçülüğün başlangıcına dair tespitler genellikle 20. yüzyıl başlangıcını işaret etmektedir ${ }^{27}$. İslamcıllı̆ın, Osmanlı İmparatorluğu'nun Avrupa topraklarındaki Müslüman tebaasının dahi devlete sadakatini sağlayamadığı fikri yeni arayışları beraberinde getirmiş; II. Abdülhamid döneminde Osmanlı'nın Avrupa'daki müttefiki, ticari partneri ve modernleşme dinamiği olmaya başlayan Almanya'nın da etkisiyle Türkçülük düşüncesi Genç Türkler arasında yaygınlaşmaya başlamıştır. 1909 yılına gelindiğinde ise, II. Abdülhamid'i tahttan indiren İttihat ve Terakki Partisi (Genç Türkler), siyasi birliğin sağlanması adına halk desteğini alabilmek için ortak bir kimlik tanımının -millet tasavvurunun- acilen gerekliliğini kavramıştır ${ }^{28}$. Nihayet Türkçülük, Türk toplumunda aydınlar ve gençler arasında Balkan Savaşlarında uğranılan bozgunlarla güçlenmiştir ${ }^{29}$. Bu döneme kadar Türkçülüğün gelişmemesinin nedeni, çok uluslu imparatorluktan vazgeçmiş görünme endişesiydi, ancak Edirne gibi Türk anayurdu sayılacak bölgelerin de elden çıkmaya başlaması ile Türkçülük daha geniş bir kitle tarafından desteklenmeye başlamıştır ${ }^{30}$.

Türkçülük, iki farklı bakış açısıyla yorumlanmaktaydı. Ziya Gökalp'in Türkçülüğü, "farklı etnik kategorilerden -Türkmen, Kürt, Çerkez...- oluşan" tebaayı, din ve kültür birliğine dayanan homojen bir millet haline getirmek isteyen bir proje iken (resmi milliyetçilik); Yusuf Akçura ise Osmanlı Türklerini, dünyadaki bütün Türkleri kucaklayan siyasi Türk milletinin parçası (etnik milliyetçilik) olarak gör-

27 Jön Türk hareketinin Abdülhamid yönetimi karşısında firkalaşma -partileşme- eğilimi gösterdiği 1902 Paris kongresi. İdris Küçükömer, Batılılaşma ve Düzenin Yabancllaşması, İstanbul, Profil Yayıncılık, 2009, s.83.

28 Marc Herzog, "Introduction", Turkey and the Politics of National Identity: Social, Economic and Cultural Transformation, Shane Brennan and Marc Herzog (eds.), NewYork, I.B.Tauris\&Co.Ltd., s.4.

29 François Georgeon, “Türk Milliyetçiliği Üzerine Düşünceler: Suyu Arayan Adam’1 Yeniden Okurken”, Milliyetçilik, Mehmet Ö. Alkan (Editör), İstanbul, İletişim Yayınlar1, 2002, s.27.

30 Sina Akşin, Kısa Türkiye Tarihi, 2. Baskı, İstanbul, Türkiye İş Bankası Kültür Yayınları, 2009, s.87. 
mekteydi ${ }^{31}$. Türklerin siyasi ve kültürel birliğini ülkü edinen bu yaklaşım pantürkist bir içerik taşıyordu.

Ziya Gökalp; Ahmet Vefik Paşa’nın "Lehçe-i Osmani”, Süleyman Paşa'nın "Tarih-i Alem" isimli kitaplarından ${ }^{32}$ çok etkilenmiş ve onları Türkçülüğün babaları olarak nitelendirmiştir. Mirza Fethali Ahunzade ve Gaspıralı İsmail'in dil milliyetçiliğine katkılarını, Hüseyinzade Ali Bey'in ortaya koyduğu “Turan” ülküsünü, Leon Cahon'ın “Asya Tarihine Giriş” kitabını, Ahmet Cevdet Bey'în "İkdam” gazetesini, "Türk Yurdu" dergisini, 1908 y1lında kurulan Türk Derneği ve 1912'de kurulan “Türk Ocağı” derneğini, Mehmed Fuad Köprülü’nün Türkiyat ve Türkoloji çalışmalarını, Türkçülügün oluşumunda önemli kilometre taşları olarak görmüştür ${ }^{33}$.

Ancak Türkçülüğün bu iki düşünürünün çalışmaları incelendiğinde, onların salt Türkçülük ideoloğu olmadıkları da anlaşılmaktadır. Ziya Gökalp, "Türkleşmek-İslamlaşmak-Muasırlaşmak" vurgusu ile uzlaştırıcı bir misyon edinmiş, Akçura ise, İslamcılık ve Türkçülük arasındaki karşılaştırmasında hangisinin daha uygun olacağ 1 konusunu çözümsüz bırakmıştır. Hatta Osmanlı'nın geleceğinin, bu iki akım arasındaki gidiş-gelişler ile şekilleneceğini düşünmüştür.

Gökalp'in fikirlerinden yararlanan Genç Türkler, devletin temeli olarak İslamiyet'in yerini Türk milliyetçiliğinin alması düşüncesinin savunucusu oldular ve ulusun bütün yetkilerin kaynağı olduğu tezi ile ortaya çıktılar ${ }^{34}$. Jön Türkler dönemindeki Türk milliyetçiliği, İslam'ın manevi ve hukuksal temellerine dokunmadan, devleti güçlendirmek adına din kurumunu çeşitli yönetsel ve yargısal işlevlerinden ayıran bir laiklik anlayışıyla gelişti. Antiemperyalist ekonomik boyutu vardı

31 Karpat, İslam'ın Siyasallaşması, s.653.

32 Meşrutiyet atılımı çok kısa sürse de, yine de dilde ve tarihte Türkçülük mücadelesinin ürünü bazı kazanımların Kanun-i Esasi'de yer alması önemlidir. Nitekim Osmanlı tarihinde ilk defa olarak 1876 Anayasası, devletin resmi dilinin Türkçe olduğunu açıkça belirtmiş, Meclis üyelerinin ve memurların Türkçe bilmesi şart koşulmuştu. Mehmet Ulusoy, Türk Devrimi ve Milliyetçilik, İstanbul, Kaynak Yayınları, 2014, s.94.

33 Ziya Gökalp, Türkçülüğün Esaslarl, 11.Bask1, İstanbul, İnkılap Kitabevi Yayın Sanayi, 2011, s.03-12.

34 Metin Heper, Türkiye'nin Siyasal Hayatı: Tarihsel, Kuramsal ve Karşılaştırmalı Açıdan, çeviren: Kadriye Göksel, İstanbul, Doğan Egmont Yayıncılık, 2011, s.342. 
ve ulusal bir ekonominin kurulması hedeflenmişti. Pantürkizm, Türk milliyetçiliğinin bir parçası/özü olarak değil, Rusya'yı zayıflatmaya yönelik bir dış politika aracı olarak kullanılıyordu ${ }^{35}$. Diğer bir deyiş ile bu milliyetçilik projesi de statükoyu korumayı, çöküşü durdurarak toprak kayıplarını önlemeyi amaçlıyordu. Türkçülük egemenliğin kaynağı olarak ulusu işaret etmesine ve ulusun bir ferdi olmayı gönüllülük esasına bağlamasına rağmen, milletin özünü "soy” miti ile özdeşleştirmesi ve diğerlerinden farklı olarak pantürkist bir siyaset uygulaması nedeniyle etnik milliyetçilik olarak değerlendirilmektedir.

Tabii Türkçülüğün, üstün 1rk iddiası ile değil de, dış politika manevrası olarak benimsenmesi pantürkist yanını zayıflatmakta idi. Ayrıca, Osmanlı İmparatorluğu'ndan bağımsızlığını kazanan etnik milliyetçilikler gibi Türkçülük de Fransız İhtilalinin sivil idealleri ile güçlendirilmişti. Smith'in bu konuyla ilgili görüşüne göre; İmparatorluklar döneminde (Habsburg, Osmanlı ve Romanov) Alman Romantizminden esinlenen ayrılıkçı Doğu Avrupa milliyetçilikleri Fransız Devrimi'nden de etkilenmişlerdi, ilk kez kitleler halk egemenliği sloganı altında tarihin öznesi haline geleceklerdi. Bu nedenle, teritoryal milletin sivil idealleri ile bu ayrılıkçı milliyetçilikler sonrası kurulan etno-siyasi milletlerin şecere bağları kaynaştırılmaya çalışılmıştır ${ }^{36}$.

Osmanlıcılık ve İslamcılığın başarısızlığının ardından, Türkçülük de tüm gayretlere rağmen Osmanlı İmparatorluğu'nun parçalanmasını engelleyememiştir. Ancak Türkçülük aynı zamanda, çöküş sonrası Kurtuluş Savaşı'nı ve İmparatorluk bakiyesi topraklar üzerinde kurulan yeni Türkiye Cumhuriyeti'nin kurucu ideolojisini besleyen en önemli birikim olma özelliğini taşımaktadır. Osmanlı İmparatorluğu'nun birlik ve bütünlügünü sağlayamayan bu proje, yeni Türk devletinin kuruluşunda farklı mahiyeti ile başarılı olmuştur. Bu nedenle etnik milliyetçilikler karşısında rasyonel cazibesini yitiren devletin gücü ile siyasi iktidarın milliyetçi ideolojisinin uyumlu olması gerektiğini ifade etmek mümkündür. Daha açık bir ifadeyle Osmanlı İmparatorluğu, son dönemlerindeki pantürkist politikalarını destekleyebilecek maddi güç

35 Kemal Karpat, Türk Siyasi Tarihi: Siyasal Sistemin Evrimi, 5.Baskı, İstanbul, Timaş Yayınlar1, 2014, s.15.

36 Anthony D. Smith, Milli Kimlik, çeviren: Bahadır Sina Şener, 5.baskı, İstanbul, İletişim Yayınları 2009, s.201. 
unsurlarına sahip değil idi. Cumhuriyet döneminde resmi milliyetçilik ile teritoryal milliyetçilik arasında dalgalı bir seyir izlemiş olan Türkçülüğün, bu dönemde ortaya çıkan ayrılıkçı etnik milliyetçiliklere rağmen başarısı, bu uyumun sağlanmasının önemini destekler niteliktedir.

\section{Sonuç}

Farklı milliyetçilik türlerini -etnik, resmi, teritoryal- açılayabilecek bir milliyetçiliği, günümüz milliyetçilik kuramları 1şığında "siyasal birim ile kültürel veya teritoryal birimin çakışmasını öngören ve çakışma alanında siyasal birimin egemenliğini meşru sayan ilke" olarak tanımlanmıştık.

$\mathrm{Bu}$ tanımdan hareketle; milliyetçiliğin sadece Türkçülüğ̈̈ nitelediği genel yaklaşımının aksine, Batıcılık dışındaki Osmanlıcılık, İslamcılık ve Türkçülük akımlarının tamamının birer milliyetçilik projesi olduğu iddia edilebilir, çünkü bu fikir akımları; siyasi iktidar (siyasal birim) ile tanımladıkları milletin (kültürel ve teritoryal birimin) uyuştuğu, dolayısıyla iktidarın egemenliğinin meşru olduğu iddiasındadırlar. Osmanlı İmparatorluğu'nun dağılmasını engellemek, içeride birlik tesis etmek maksadıyla geliştirilen bu son dönem milliyetçiliklerinin, etnik farklılıkları bir arada yaşatmaya çalışan teritoryal milliyetçilik projesi olduklarını söylemek genellikle mümkündür. Sadece Türkçülügün, diş siyaset gereği de olsa pantürkist içeriği nedeniyle etnik milliyetçilik olduğu -Cumhuriyet dönemi Türkçülügüü, resmi milliyetçilikteritoryal milliyetçilik arasındaki salınımlar tarihidir-, ifade edilmekle beraber, o da dönemin ayrılıkçı etnik milliyetçilikleri gibi bazı teritoryal nitelikler taşımaktadır. Egemenliğin kaynağı olarak "ulus"u göstermesinin yanında, millete katılımın gönüllülük esasına dayandırılması bu özelliğini daha da güçlendirmektedir.

Osmanlı İmparatorluğu'nda benimsenen Osmanlıcılık, İslamc1lık ve Türkçülük gibi milliyetçilikler ile tarihi gelişmelere paralel olarak son kertede elde kalan toprakları kaybetmeden siyasi birliği korumak hedeflenmiş, milletin tanımı sahip olunan topraklara göre revize edilerek, teritoryal milliyetçilik gereği tüm etnik unsurların merkezi iktidarda temsil edilmeleri sağlanmıştır. Hatta tek bir entelijensiyanın, örneğin Genç Türklerin Türkçülükten önce Osmanlıcılığı ve İslamcılı- 
$\breve{g} 1$ da savundukları dikkate alınırsa ${ }^{37}$ iktidarların milliyetçilik konusuna pragmatist yaklaştıkları ifade edilebilir. Durgun, Türk siyasal hayatında milliyetçiliklerin devlet tarafından siyasi bir aygıt olarak kullanıldığını düşünmektedir ${ }^{38}$, yani Osmanlı son dönemlerinden itibaren iktidarların reel-politiğe en uygun milliyetçiliği kitleselleştirme çabaları, milliyetçiliğin, ayrılıkçı etnik taleplerin aşılması maksadıyla devlet tarafından araçsallaştırıldığını teyit etmektedir.

Buna rağmen; Osmanlı İmparatorluğu'nu kurtarmaya yönelik genellikle teritoryal nitelikli milliyetçilikler, ayrılıkçı etnik milliyetçilikler karşısında başarısız olmuşlardır. Etnik milliyetçiliklerin Fransız İhtilali'nin sivil ideallerinden yararlanmaları, emperyalist devletlerin İmparatorluk sınırlarına yönelik çıkarları, İmparatorluğun son dönemde alt etnisiteler için rasyonel cazibesini yitirmiş olması ve devletin takip ettiği milliyetçi ideolojileri destekleyebilecek gücünün kalmaması ayrılıkçı etnik milliyetçiliklerin kendi devletlerini kurmalarında belirleyici rol oynamışlardır.

Günümüz Türkiye'sinin siyasal kompozisyonuna bakıldığında ise, bu fikir akımlarının halen farklı fraksiyonların milliyetçilik yaklaşımlarına kaynaklık ettiği ve üzerinde henüz bir konsensüs oluşmadığı söylenebilir. Her ne kadar bu farklılık, siyasal iktidarların değişimiyle ülke içinde milli birliğin harcının dönemsel olarak eksen değiştirmesine, ülke dışında ise dış politikamızda kırılmalara neden olsa da; bir asırdan fazla zamandır süregelen bu görüşler arasında ulaşılan siyasal dengenin olgunlaşmış olduğunu ve aslında milli birliğin devamı için devlet aygıtına alternatif sağladığını da söylemek mümkündür.

37 İttihat ve Terakki'nin her üç milliyetçilik projesini de desteklemiş olması bugün için bir bocalama gibi gözükse de, bu durum cemiyete aynı zamanda daha rahat bir hareket alanı sağlıyordu. Kerem Ünüvar, "Ziya Gökalp”, Milliyetçilik, Mehmet Ö. Alkan (Editör), İstanbul, İletişim Yayınları, 2002, s.30.

38 Şenol Durgun, “Türk Milliyetçiliğinden Türkiye Milliyetçiliğine: Resmi Anlayıştaki Farklılaşmalar, Sorunlar”, Ulus İnşası ve Milliyetçilik, Şenol Durgun (Editör), Ankara, Binyıl Yayınevi, 2014, s.80. 


\section{Kaynakça}

Akçura, Yusuf. "Üç Tarz-1 Siyaset”. Üç Tarz-1 Siyaset: Yusuf Akçura, Mehmet Ali Erdem (Editör), 2.Baskı. Ankara: Lotus Yayınevi, 2005.

Akşin, Sina. Kısa Türkiye Tarihi, 2. Baskı. İstanbul: İş Bankası Kültür Yayınları, 2009.

Armaoğlu, Fahir H. Siyasi Tarih 1789-1960. Ankara: Sevinç Matbaa, 1964.

Aslantaş, Selim. "Sırp İsyanları (1804-1815): Milli Bağımsızlık Hareketi mi, Burjuva Devrimi mi, Köylü Ayaklanması mı?” Doğu Batı 39, 7 (2006) :83-96.

Başak, Suna. Kültür Olgusu Analizleri ve Üç Tarz-ı Siyaset. Ankara: Odak Yayınevi, 2004.

Bozgöz, Faruk. “Arap Milliyetçiliği.” Doğu Batı 39, 7 (2006): 97-112.

Boztemur, Recep. "Irak Milliyetçiliği: Toplumsal Bütünleşmede Ordunun Rolü ve Devletin Meşruluk Temelleri." Doğu Batı 39, 7 (2006): 60-81.

Çilliler, Yavuz. Etnik Sorunlar, Demokratikleşme ve Bask Milliyetçili$\breve{g i}$. Ankara: Alter Yayıncılık, 2014.

Durgun, Şenol. "Türk Milliyetçiliğinden Türkiye Milliyetçiliğine: Resmi Anlayıştaki Farklılaşmalar, Sorunlar." Ulus İņ̧ası ve Milliyetçilik, Editör: Şenol Durgun, 57-90. Ankara: Binyıl Yayınevi, 2014.

Gellner, Ernest. Uluslar ve Ulusçuluk. Çeviren: Büşra Ersanlı ve Günay Göksu Özdoğan, 2.baskı. İstanbul: Hil Yayın, 2008.

Georgeon, François. "Türk Milliyetçiliği Üzerine Düşünceler: Suyu Arayan Adam'1 Yeniden Okurken." Milliyetçilik, Editör: Mehmet Ö. Alkan, 23-36. İstanbul: İletişim Yayınları, 2002.

Gökalp, Ziya. Türkçülüğün Esasları, 11.Baskı. İstanbul: İnkılap Kitabevi Yayın Sanayi, 2011.

Greenfeld, Liah. "Alman Milliyetçiliğinin Doğuşu.” Çeviren: Yasemin Şahin. Doğu Batı 10, 39, (Kasım-Ocak 2006-2007): 30-57.

Heper, Metin. Türkiye'nin Siyasal Hayatt: Tarihsel, Kuramsal ve Karşılaştırmalı Açıdan. Çeviren: Kadriye Göksel. İstanbul: Doğan Egmont Yayıncılık, 2011. 
Herzog, Marc. Introduction to Turkey and the Politics of National Identity: Social, Economic and Cultural Transformation, Edited by Shane Brennan and Marc Herzog. NewYork,: I.B. Tauris \& Co. Ltd.

İnalcık, Halil. Osmanlılar: Fütühat, İmparatorluk, Avrupa ile İlişkiler. İstanbul: Timaş Yayınları, 2010.

Karpat, Kemal. İslam'ın Siyasallaşması, 4.Bask1. İstanbul: İstanbul Bilgi Üniversitesi Yayınları, 2010.

Karpat, Kemal. Türk Siyasi Tarihi: Siyasal Sistemin Evrimi, 5.Bask1. İstanbul: Timaş Yayınları, 2014.

Kohn, Hans. "Western and Eastern Nationalisms." Nationalism, Edited by John Hutchinson and Anthony D.Smith, 162-165. New York: Oxford University Press, 1994.

Kongar, Emre. Tarihimizle Yüzleşmek. İstanbul: Remzi Kitabevi, 2006.

Küçükömer, İdris. Batılılaşma ve Düzenin Yabancılaşması. İstanbul: Profil Yayıncilik, 2009.

Mardin, Şerif. "19. Yüzyılda Düşünce Akımları ve Osmanlı Devleti.” Şerif Mardin: Türk Modernleşmesi, Editörler: Mümtazer Türköne, ve Tuncay Önder, 81-100. İstanbul: İletişim Yayınları.

Ortaylı, İlber ve Akyol, Taha. Osmanlı Mirası, 1. Baskı. İstanbul: Timaş Yayınları, 2010.

Özcan, Azmi. "Osmanlıcıllk." Diyanet İslam Ansiklopedisi, cilt 33. Ankara: Türkiye Diyanet Vakfı Yayınları, 2007.

Özkırımlı, Umut. Milliyetçilik Kuramları: Eleştirel Bir Baklş, 3.Baskı. Ankara: Doğu Batı Yayınları, 2009.

Palmer, Alan. Verfall und Untergang des Osmanischen Reiches. Translated by Maria Rosken and Ilse Strasmann. München: Wilhelm Heyne Verlag, 1992.

Smith, Anthony D. Ethno-Symbolism and Nationalism: A Cultural Approach. New York: Routledge, 2009.

Smith, Anthony D. Milli Kimlik. Çeviren: Bahadır Sina Şener, 5.baskı. İstanbul: İletişim Yayınları, 2009.

Tunaya, Tarık Zafer. Türkiye'de Siyasal Gelişmeler (1876-1938), Mütareke, Cumhuriyet ve Atatürk, 3. Bask1. İstanbul: İstanbul Bilgi Üniversitesi Yayınları, 2009. 
Ulusoy, Mehmet. Türk Devrimi ve Milliyetçilik. İstanbul: Kaynak Yayınları, 2014.

Ülken, Hilmi Ziya. Türkiye'de Çağdaş Düşünce Tarihi, 2.Baskı. İstanbul: Ülken Yayınları, 1979.

Ünüvar, Kerem. "Ziya Gökalp.” Milliyetçilik, Editör: Mehmet Ö. Alkan, 28-35. İstanbul: İletişim Yayınları, 2002.

Yılmaz, Veli. Siyasi Tarih. İstanbul: Harp Akademileri Basımevi, 1998. 